\title{
An updated mortality study of workers in three major United States refineries and chemical plants
}

\author{
Leba G Shallenberger, John F Acquavella, Donna Donaleski
}

\begin{abstract}
A historical cohort study of refinery and chemical plant workers, originally observed from 1970 to 1977 , was updated to the end of 1982. This cohort included 25321 active, retired, and terminated workers at the Exxon refineries and chemical plants in Baton Rouge, Louisiana; Baytown, Texas; and Bayway/ Bayonne, New Jersey. An emphasis was placed on the cancers previously reported to be increased in at least one petrochemical worker population. The population included a high proportion of retirees, providing adequate work experience and latency to evaluate risks associated with employment. Vital status was determined for $98.3 \%$ of the population and death certificates were obtained for $99.9 \%$ of the decedents. Mortality for "all causes of death" (standardised mortality ratio (SMR) = $89,95 \%$ confidence interval $(95 \% \mathrm{CI}) 87-91)$ and for "all cancers" (SMR $=94,95 \%$ CI 89-100) were lower than expected based on state rates. History of cigarette smoking collected from individual medical records and summarised work histories were used for subgroup analyses. There was no indication that cancers of primary interest were increased; however, blue collar workers at one plant had raised rates of kidney cancer $(S M R=246,95 \%$ CI $146-$ $390)$, which may require further evaluation.
\end{abstract}

Across the refinery and petrochemical industry, workers have been found to experience lower mortality from all causes combined and from all cancers combined compared with rates for the general population, ${ }^{1-9}$ (and Morgan RW and Wong $\mathrm{O}$, personal communication). There have, however,

Exxon Company USA, Health Services Department, Houston, Texas, USA

L G Shallenberger

Monsanto Company, Saint Louis, Missouri, USA

J F Acquavella

Exxon Biochemical Sciences, Inc, East Millstone, New Jersey, USA

D Donaleski been inconsistent reports of increased rates for specific cancers including kidney cancer, malignant melanoma, central nervous system (CNS) and brain cancer, and cancers of the haematopoietic and lymphatic systems. ${ }^{9}$ The International Agency for Research on Cancer (IARC) recently reviewed epidemiological studies of refinery workers ${ }^{10}$ and classified the refinery environment as $2 \mathrm{~A}$, probably carcinogenic to human subjects. This assessment was based primarily on interpretation by IARC of the evidence that leukaemia and malignant melanoma rates are higher than expected among refinery workers. A recent academic review of studies on refinery workers ${ }^{9}$ reached a different conclusion than IARC, judging the evidence to be insufficient to conclude that the refinery environment was probably carcinogenic to workers.

The 1970-7 Exxon cohort study ${ }^{12}$ had standardised mortality ratios (SMRs) less than 100 for most causes of death except for non-significant excesses in cancers of the kidney and CNS and brain. At one of the three study locations, the Baton Rouge plant, there was an excess of pancreatic cancer. This result was further evaluated by Louisiana State University investigators studying increased pancreatic cancer rates in Louisiana. Thus far, published findings have suggested associations with lifestyle, including Cajun ancestry, moderate cigarette smoking, and consumption of pork products and rice. ${ }^{11}$ Raised SMRs for digestive organ and respiratory site cancers in the New Jersey plants (Bayway and Bayonne), based on United States rates, were further evaluated using state and local county rates to calculate expected numbers. The observed and expected numbers were equivalent using these rates, suggesting that the increased rates in New Jersey as compared with the total United States rates were responsible for these excesses.

With the previous background, the present follow up study was planned to update mortality for this cohort. This report is particularly timely in the light of the recent IARC review and the rising public concern about potential occupational hazards.

Plant descriptions

The three refineries have been operating since the late 
1800s (Bayonne) or early 1900s. Early technology such as shell stills or thermal cracking coils were replaced before or during the 1940s and 1950s with modern processes such as pipestills, catalytic cracking, alkylation, and catalytic reforming. Baytown and Baton Rouge produce a wide range of motor oils and other lubricants using deasphalting, dewaxing, and extraction. Baytown, and to a lesser extent Baton Rouge, also produce a wide range of petroleum solvents and other specialty products using fractionation, extraction, and hydrofinishing. During the second world war Baytown was a major producer of high test aviation fuel and toluene for explosives (TNT), and both Baytown and Baton Rouge produced raw materials for synthetic rubber.

All three refineries produce a full range of fuel products, using essentially the same type of processes. Because Baytown and Bayway have used higher sulphur and heavier crude oils longer, they began installing desulphurisation processes earlier. Baton Rouge has used coking to produce electrode grade coke since about the 1960 s. Baytown did not install coking until the 1980s, and Bayway historically has sold the heavy crude fractions as residual fuel oil.

The three petrochemical plants included in this study were similar in terms of their mode of operation and degree of exposure control but different in size and products. The Baton Rouge chemical plant is the largest of the three and starts with various gas and liquid cracking units and a partial oxidation unit to produce olefins and other intermediates. These are used to manufacture phthalic anhydride, alcohols, isopropanol, neoacids and aromatic compounds. The plant also includes facilities for making synthetic rubber. The Baytown chemical plant, which is smaller than Baton Rouge, emphasised the extraction of aromatic compounds (such as benzene, toluene, and xylene), the production of butyl rubber, polypropylene, cyclohexane, butadiene, isobutylene, and linear paraffins. The Bayway chemical plant near Linden, New Jersey, is the smallest of the three. At the time of the study it produced various motor oil additives, some ketones, and a low molecular weight polymer.

\section{Materials and methods \\ COHORT DEFINITION}

The study population included all regular employees with at least one month service at the Baton Rouge, Louisiana, Baytown, Texas, and/or Bayway/ Bayonne, New Jersey refinery and chemical plant sites during the period 1 January 1970 to 31 December 1982. Also, employees who had retired before 1970 and were still alive at 1 January 1970 were included in the study population.

\section{DATA COLLECTION AND HANDLING}

Company personnel and payroll records provided demographic information and work history. Most of the death certificates for deceased workers were readily available from annuitant benefit records. Missing death certificates were traced through the Social Security Administration (SSA) and the National Death Index (NDI). ${ }^{12}$ The underlying cause of death was coded by a trained nosologist according to the eighth revision of the International Classification of Diseases. ${ }^{13}$

\section{VITAL STATUS FOLLOW UP}

Vital status was determined by a hierarchical approach beginning with information from company records. The first step in this process was to determine those active employees and annuitants who were alive or deceased according to company records. For those who were deceased, death certificates were obtained, when available, from company files. The remainder of the cohort was submitted to the SSA and the NDI. For potential decedents identified by the NDI, death certificates were requested from the respective states and verified with company information available on each study subject. The SSA search provided an indication of workers as alive (currently paying into SSA or receiving benefits), deceased, or unknown (not currently paying into SSA). Again, death certificates were requested from the respective states and compared with information from company records. Those designated by SSA as alive received the same designation in our study database. Those remaining $(n=429,1 \cdot 7 \%)$ were considered lost to follow up.

\section{DATA QUALITY CONTROL}

Extensive quality control procedures were employed throughout the course of the study to ensure cohort completeness, data accuracy, and consistency. These included cross checks among different record sources and data audits. Special attention was paid to the quality of the death certificate coding, which was evaluated by sending a sample of the death certificates to the National Centre for Health Statistics (NCHS) for review. All death certificates with cancer mentioned, plus an additional randomly selected group of about 1400 certificates, totalling $54 \%$ of all deaths, were included in the sample for review. Based on this sample, the upper $95 \%$ confidence interval $(95 \% \mathrm{CI})$ for the error rate for coding the underlying cause of death was less than $1 \%$.

\section{STATISTICAL METHODS}

Employees who were active before 1 January 1970 contributed person-years starting from 1 February, and new employees hired after 1 January 1970 contributed person-years from their date of employment plus one month, until the end of the 
study period (31 December 1982) or their date of death, whichever came first. Those who retired before 1 January 1970, contributed person-years throughout the study period or until date of death. Employees who terminated during the study period without reaching retirement age were considered at risk until the end of the study period unless they were designated as lost to follow up by our searches of company records, SSA, and NDI. In that case, workers who were lost to follow up contributed person years only until their date of termination from company service.

Mortalities for workers were compared with those of the general population for the states in which their respective plants were located, by the calculation of SMRs. The SMR is most often expressed as the ratio of observed to expected deaths multiplied by 100 . Expected deaths for workers were calculated by multiplying death rates for Louisiana, Texas, and New Jersey, specific for age, sex, race, and calendar period, by the corresponding worker person-years at plants in those specific states. ${ }^{14} 15$ The SMRs were designated as statistically significant if the $\mathbf{9 5 \%}$ CIs did not include 100. Rough CI calculations were used when the number of observed deaths exceeded five; Fisher's exact CIs were calculated in other instances. ${ }^{16}$

A main occupation was derived for each employee by summarising the individual work histories and determining the occupation in which each employee spent the largest proportion of his or her time. The SMRs were calculated for blue collar workers (the occupational groups with potential for daily exposure to petroleum, petrochemicals, and other related substances) and white collar workers. The following categories were used: blue collar, consisting of process operators, mechanics, and labourers and white collar consisting of managers, professionals, technicians, office workers, service workers, laboratory workers, and field professionals.

This categorisation reflects a slight change from that used in the original cohort study. ${ }^{2}$ In that study, laboratory workers were categorised as blue collar workers. Subsequent discussions with company industrial hygienists suggested that the nature of potential exposures for laboratory workers is different from that of those working on the plant units. Additional analyses were also examined to consider laboratory workers separately.

Information on smoking history was abstracted from the plant medical records for the 1970-7 cohort population. Further information was not collected for employees hired during the five year update period. "Smokers" were those who ever smoked and "non-smokers" never smoked. Those with no smoking information in their records were classified as "smoking unknown".

\section{Results}

STUDY POPULATION DESCRIPTION

The total study population of 25321 employees and retirees contributed 232921 person-years during the 13 year period. During the five year study update period, 3623 new employees and 95218 person-years were added (table 1).

The study population included 19083 employees who were active for at least one month during the study period and 6238 retirees who were still alive at 1 January 1970 . At the end of the observation period $39.6 \%(n=10032)$ of the total cohort were alive and still employed; another $1.7 \%(n=422)$ died while employed. Forty seven per cent $(n=11973)$ had retired before or during the study period (fig 1 ).

Employees who had terminated employment before reaching retirement age accounted for $11.4 \%$ $(n=2895)$ of the study population. Only $1 \cdot 7 \%$ $(n=429)$ of the total population were lost to follow up (table 1). Ninety four per cent of this group were less than 40 years old at last observation. Seventy two per cent had worked less than five years; $92.3 \%$ had worked less than 10 years.

The total study population comprised $82 \%$ white men, $10 \%$ black men, $8 \%$ white women, and $1 \%$ black women. The study population had a bimodal age distribution with peaks in the $30-39(24 \%)$ and 70 or older $(28 \%)$ age groups at last observation. Roughly $48 \%$ of the population had worked for Exxon for 25 years or more. Twenty six per cent were hired before 1940 , and $24.5 \%$ began employment between 1940 and 1949 . Twenty per cent were hired

Table 1 Vital status: total study population 1970-82 by plant site

\begin{tabular}{|c|c|c|c|c|}
\hline & Baton Rouge No (\%) & Baytown No (\%) & Bayrway/Bayonne No (\%) & $1970-82$ totals $N o(\%)$ \\
\hline $\begin{array}{l}\text { Alive } \\
\text { Dead } \\
\text { Lost to follow up }\end{array}$ & $\begin{array}{l}7709(77 \cdot 9) \\
2000(20 \cdot 2) \\
185(1.9)\end{array}$ & $\begin{array}{l}7213(82 \cdot 7) \\
1374(15 \cdot 8) \\
135(1 \cdot 5)\end{array}$ & $\begin{array}{l}4924(71 \cdot 8) \\
1826(26 \cdot 6) \\
110(1 \cdot 6)\end{array}$ & $\begin{array}{c}19693(77 \cdot 8) \\
5199^{\star}(20 \cdot 5) \\
429(1 \cdot 7)\end{array}$ \\
\hline $\begin{array}{l}\text { Total workers } \dagger \\
\text { Person-years }\end{array}$ & $\begin{array}{r}9894 \\
93785\end{array}$ & $\begin{array}{r}8722 \\
80684\end{array}$ & $\begin{array}{r}6860 \\
59257\end{array}$ & $\begin{array}{r}25321 \\
232921\end{array}$ \\
\hline
\end{tabular}

*One death occurred in a person who worked at two study locations; he was counted once in the total.

†Includes 150 employees who worked at more than one of the three plants. 


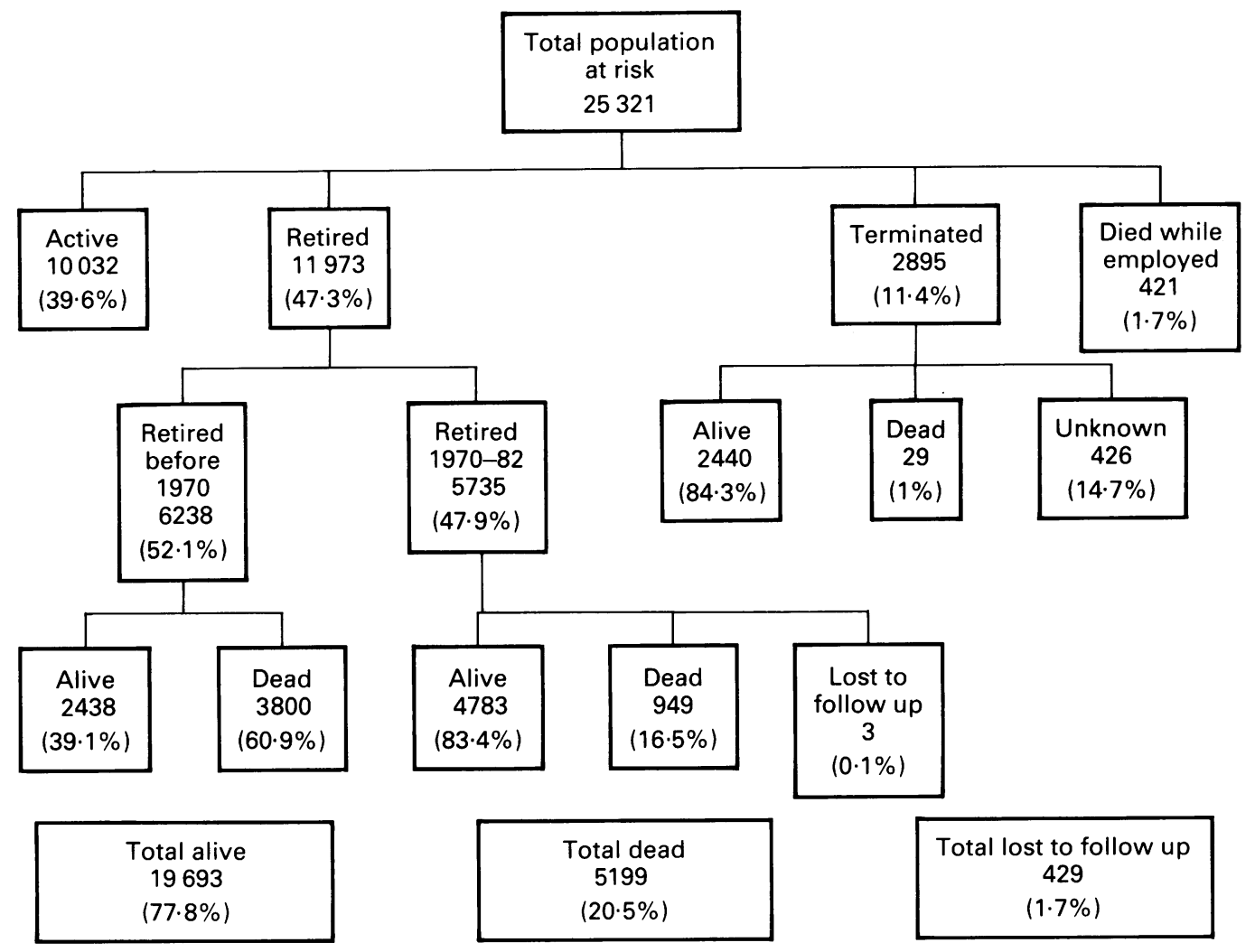

Figure 1 Total study population 1970-82.

during the original eight year observation period and $14 \%$ of the cohort were hired during the five year update period.

Over the 1970-82 study period, there was a total of 5199 deaths, of which 1995 occurred during the update period. The 5199 deaths were evenly distributed by year from 1970-82. Seventy three per cent of all the deaths were pre- 1970 retirees and $18 \%$ were persons who retired during the study period. Death certificates were available for all but five $(0 \cdot 1 \%)$ of the known deaths. These five deaths were included in the SMRs for all causes combined but were not apportioned to specific cause of death categories.

Blue collar workers accounted for around two thirds of the workforce at each of the three plants. One per cent of the workers at Baton Rouge and Bayway/Bayonne and $4 \%$ at Baytown had missing work histories.

Smoking state was determined for $70 \%$ of the 1970-7 study population, from medical record data (fig 2). No additional data were collected for those who entered the cohort after 1977. For the total 1970-82 population, among those with known smoking histories, $44 \%$ were or had been smokers includ- ing $32 \%$ smokers among white collar workers and $50 \%$ among blue collar workers.

MORTALITY ANALYSES: TOTAL STUDY POPULATION Table 2 presents the SMRs for the total population and three plant populations. The SMRs cannot be directly compared with each other; however, general trends can be noted. The SMRs for all causes of death were significantly low for Baton Rouge (SMR $=86,95 \%$ CI 82-90), Baytown $(\mathrm{SMR}=85$, 95\% CI 81-90), and the total population (SMR $=89,95 \%$ CI 87-91); whereas for Bayway/ Bayonne the SMR was slightly lower than expected (SMR $=97,95 \%$ CI 93-102). The SMRs for most major causes of death were lower than expected. Significant deficits were found in the SMRs for the following: diseases of the respiratory system and for all external causes at all three plant sites; diseases of the digestive system, and for ill defined conditions at Baton Rouge, Baytown, and for the total population. Ischaemic heart disease SMRs were around 100 for all three plant sites and for the total population.

The SMRs for all cancers were significantly low for Baton Rouge (SMR $=91,95 \%$ CI 83-100), Bay- 


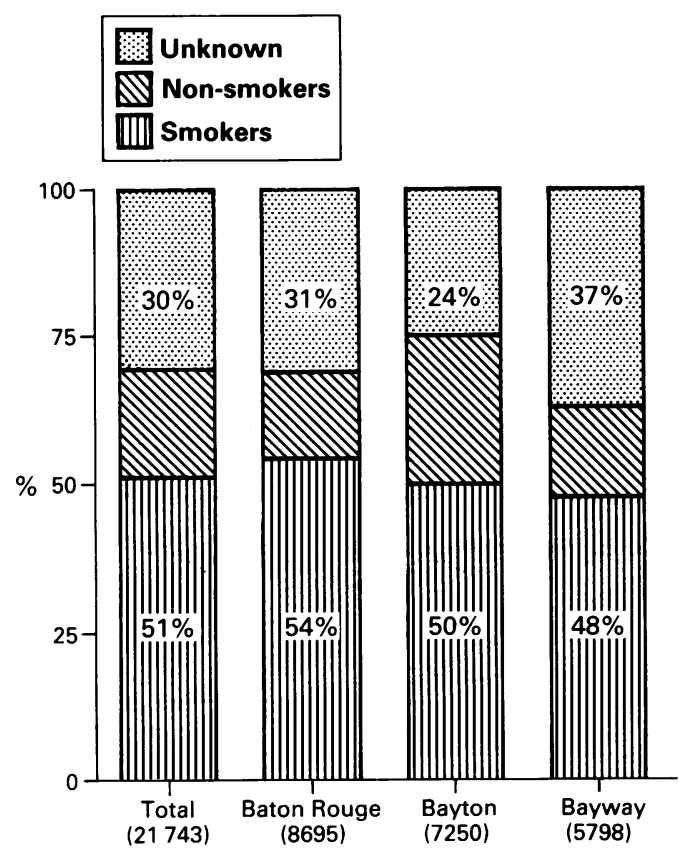

Figure 2 Refinery/chemical plant cohort smoking data from medical records by site 1970-7. Number in parenthesestotal site population.

town (SMR $=87,95 \%$ CI 78-97), and for the total population (SMR $=94,95 \%$ CI 89-100). For Bayway/Bayonne, the observed number of cancer deaths was consistent with the expected number $($ SMR $=103,95 \%$ CI 93-114). Significant deficits were found in the SMRs for lung cancer at Baton Rouge, Baytown, and for the total population. The SMR for pancreatic cancer was increased at Baton Rouge $($ SMR $=139,95 \%$ CI 98-191), but there was a significant deficit for the SMR at Bayway/Bayonne (SMR $=55,95 \%$ CI 27-98). Mortality from kidney cancer was significantly high at Baton Rouge $(\mathrm{SMR}=192,95 \%$ CI 113-303), but was similar to expected values at the other two plant sites. Mortality from brain cancer was increased at Baytown $(\mathrm{SMR}=156,95 \%$ CI 80-272), and Baton Rouge $(S M R=121,95 \%$ CI 55-231) and lower than expected at Bayway/Bayonne (SMR $=67,95 \% \mathrm{CI}$ 18-171). For oesophageal cancer, the SMRs were moderately increased at all three plant sites. The number of deaths from all haematopoietic and lymphatic system cancers was slightly increased at Baton Rouge (SMR $=125,95 \%$ CI 93-165), and similar to the expected number at the other two plant sites.

\section{WORK HISTORY AND SMOKING ANALYSIS}

Tables 3 and 4 show the SMRs for white collar and blue collar workers categorised as smokers, nonsmokers, and unknown smokers. In these and subsequent tables, the analyses focused on cancer sites that showed increases in previous petrochemical studies. ${ }^{9}$ Most of the SMRs were less than 100 . For blue and white collar workers, the SMRs were higher for smokers compared with non-smokers for most causes of death. No significant excesses occurred in the white collar group (table 4). White collar nonsmokers had significant deficits for all causes (SMR $=48,95 \%$ CI 39-59), ischaemic heart disease (SMR $=59,95 \%$ CI 43-80), and all cancers $(\mathrm{SMR}=47,95 \%$ CI 30-71). Blue collar nonsmokers also had significant deficits for all causes (SMR $=51,95 \%$ CI 45-57), ischaemic heart disease (SMR $=70,95 \%$ CI 59-82), and all cancers (SMR $=46,95 \%$ CI 35-59). Blue collar workers with smoking unknown had a significantly raised SMR for ischaemic heart disease. Blue collar smok-

Table 2 SMRs for selected causes of death for the three plant populations and total study population at risk, 1970-82

\begin{tabular}{|c|c|c|c|c|c|c|c|c|}
\hline \multirow[b]{2}{*}{ Cause of death (ICD-8) } & \multicolumn{2}{|c|}{ Baton Rouge } & \multicolumn{2}{|c|}{ Baytown } & \multicolumn{2}{|c|}{ Bayway/Bayonne } & \multicolumn{2}{|c|}{ Total population } \\
\hline & $O b s$ & $S M R$ & Obs & $S M R$ & Obs & $S M R$ & Obs & $S M R$ \\
\hline $\begin{array}{l}\text { All causes of death (001-998) } \\
\text { Ischaemic heart disease }(410-413) \\
\text { Disease of respiratory system (460-519) } \\
\text { All cancers }(140-209) \\
\text { Oesophagus (150) } \\
\text { Stomach (151) } \\
\text { Large intestine (153) } \\
\text { Pancreas (157) } \\
\text { Lung (162) } \\
\text { Skin-melanoma (172) } \\
\text { Kidney (189) } \\
\text { Brain/CNS (191-192) } \\
\text { All haematopoietic and lymphatic } \\
\text { (200-209) } \\
\text { Leukaemia (204-207) } \\
\text { Lympho/reticulosarcoma (200) } \\
\text { Other lymph (202-203. 208-209) }\end{array}$ & $\begin{array}{r}2000 \\
859 \\
102 \\
448 \\
12 \\
15 \\
39 \\
38 \\
152 \\
5 \\
18 \\
9 \\
\\
5 \\
\\
23 \\
9 \\
17\end{array}$ & $\begin{array}{c}86^{\star} \\
100 \\
66^{\star} \\
91^{\star} \\
117 \\
75 \\
104 \\
139 \\
85^{\star} \\
80 \\
192^{\star} \\
121 \\
125 \\
129 \\
156 \\
122\end{array}$ & $\begin{array}{r}1374 \\
545 \\
93 \\
308 \\
9 \\
12 \\
23 \\
17 \\
98 \\
5 \\
8 \\
12 \\
\\
32 \\
15 \\
6 \\
9\end{array}$ & $\begin{array}{c}85^{\star} \\
102 \\
77^{\star} \\
87^{\star} \\
125 \\
93 \\
82 \\
86 \\
76^{\star} \\
74 \\
97 \\
156 \\
103 \\
114 \\
117 \\
84\end{array}$ & $\begin{array}{r}1826 \\
856 \\
90 \\
402 \\
11 \\
26 \\
51 \\
11 \\
116 \\
4 \\
9 \\
4 \\
\\
30 \\
9 \\
6 \\
14\end{array}$ & $\begin{array}{c}97 \\
104 \\
72^{\star} \\
103 \\
126 \\
125 \\
107 \\
55^{\star} \\
103 \\
74 \\
114 \\
67 \\
99 \\
68 \\
111 \\
141\end{array}$ & $\begin{array}{r}5199 \dagger \\
2260 \\
285 \\
1158 \\
32 \\
53 \\
113 \\
66 \\
366 \\
14 \\
35 \\
25 \\
\\
111 \\
46 \\
21 \\
40\end{array}$ & $\begin{array}{c}89^{\star} \\
102 \\
71^{\star} \\
94^{\star} \\
122 \\
99 \\
100 \\
98 \\
87^{\star} \\
76 \\
137 \\
119 \\
110 \\
104 \\
129 \\
116\end{array}$ \\
\hline
\end{tabular}

^Statistically significant based on $95 \% \mathrm{CIs}$.

+One death occurred in a person who worked at two study locations; he was counted once in the total population catculations. 
Table 3 SMRs for selected causes of deaths $\nmid$ for white collar workers by smoking stateł, 1970-82

\begin{tabular}{|c|c|c|c|c|c|c|c|c|}
\hline & \multicolumn{2}{|c|}{ Total } & \multicolumn{2}{|c|}{ Smokers } & \multicolumn{2}{|c|}{ Non-smokers } & \multicolumn{2}{|c|}{ Smoking unknown } \\
\hline & Obs & $S M R$ & Obs & $S M R$ & Obs & $S M R$ & Obs & $S M R$ \\
\hline $\begin{array}{l}\text { All causes } \\
\text { Ischaemic heart disease } \\
\text { All cancers } \\
\text { Pancreas } \\
\text { Kidney } \\
\text { Skin-melanoma } \\
\text { CNS/brain } \\
\text { All haematopoietic and lymphatic } \\
\text { Leukaemia } \\
\text { Lympho/reticulosarcoma } \\
\text { Other lymph } \\
\text { Benign neoplasms }\end{array}$ & $\begin{array}{r}937 \\
376 \\
217 \\
10 \\
5 \\
2 \\
7 \\
28 \\
15 \\
4 \\
7 \\
4\end{array}$ & $\begin{array}{r}79^{\star} \\
85^{\star} \\
84^{\star} \\
71 \\
89 \\
46 \\
131 \\
127 \\
159 \\
119 \\
95 \\
152\end{array}$ & $\begin{array}{r}505 \\
200 \\
125 \\
6 \\
3 \\
2 \\
5 \\
13 \\
5 \\
3 \\
4 \\
1\end{array}$ & $\begin{array}{r}90 \star \\
94 \\
95 \\
84 \\
101 \\
93 \\
177 \\
120 \\
111 \\
160 \\
107 \\
75\end{array}$ & $\begin{array}{r}98 \\
42 \\
23 \\
1 \\
0 \\
0 \\
1 \\
4 \\
3 \\
1 \\
0 \\
0\end{array}$ & $\begin{array}{r}48^{\star} \\
59^{\star} \\
47^{\star} \\
38 \\
0 \\
0 \\
82 \\
95 \\
174 \\
138 \\
0 \\
0\end{array}$ & $\begin{array}{r}334 \\
134 \\
69 \\
3 \\
2 \\
0 \\
1 \\
11 \\
7 \\
0 \\
3 \\
3\end{array}$ & $\begin{array}{r}81^{\star} \\
86^{\star} \\
89 \\
72 \\
132 \\
0 \\
78 \\
158 \\
221 \\
0 \\
138 \\
375\end{array}$ \\
\hline
\end{tabular}

* Statistically significant based on $95 \%$ CIS.

† Selected causes of death in this table are consistent with those emphasised in other refinery and petrochemical worker studies.

$\$$ Not collected for 1978-82 new employees.

Table 4 SMRs for selected causes of death $\dagger$ for blue collar workers by smoking state $\ddagger$, 1970-82

\begin{tabular}{|c|c|c|c|c|c|c|c|c|}
\hline & \multicolumn{2}{|l|}{ Total } & \multicolumn{2}{|c|}{ Smokers } & \multicolumn{2}{|c|}{ Non-smokers } & \multicolumn{2}{|c|}{ Smoking unknown } \\
\hline & Obs & $S M R$ & Obs & $S M R$ & Obs & $S M R$ & Obs & $S M R$ \\
\hline $\begin{array}{l}\text { All causes } \\
\text { Ischaemic heart disease } \\
\text { All cancers } \\
\text { Pancreas } \\
\text { Kidney } \\
\text { Skin-melanoma } \\
\text { CNS/brain } \\
\text { All haematopoietic and lymphatic } \\
\text { Leukaemia } \\
\text { Lympho/reticulosarcoma } \\
\text { Other lymph } \\
\text { Benign neoplasms }\end{array}$ & $\begin{array}{r}4121 \\
1783 \\
918 \\
56 \\
29 \\
12 \\
18 \\
82 \\
30 \\
17 \\
32 \\
11\end{array}$ & $\begin{array}{r}91^{\star} \\
102 \\
95 \\
107 \\
149 \\
87 \\
117 \\
106 \\
88 \\
138 \\
120 \\
117\end{array}$ & $\begin{array}{r}2101 \\
910 \\
544 \\
29 \\
21 \\
7 \\
10 \\
47 \\
19 \\
8 \\
19 \\
6\end{array}$ & $\begin{array}{l}91^{\star} \\
105 \\
104 \\
102 \\
193^{\star} \\
96 \\
107 \\
113 \\
108 \\
120 \\
129 \\
114\end{array}$ & $\begin{array}{r}302 \\
147 \\
61 \\
10 \\
2 \\
2 \\
6 \\
5 \\
2 \\
2 \\
1 \\
1\end{array}$ & $\begin{array}{r}51^{\star} \\
70^{\star} \\
46^{\star} \\
137 \\
70 \\
98 \\
232 \\
46 \\
43 \\
114 \\
26 \\
78\end{array}$ & $\begin{array}{r}1718 \\
768 \\
313 \\
17 \\
6 \\
3 \\
2 \\
30 \\
9 \\
7 \\
12 \\
4\end{array}$ & $\begin{array}{c}104 \\
116^{\star} \\
102 \\
102 \\
104 \\
69 \\
57 \\
119 \\
77 \\
177 \\
147 \\
140\end{array}$ \\
\hline
\end{tabular}

«Statistically significant based on $95 \%$ CIs.

† Selected causes of death in this table are consistent with those emphasised in other refinery and petrochemical worker studies.

¥Not collected for 1978-82 new employees.

Table 5 SMRs for selected cancer deaths for Baton Rouge workers by job category and smoking state $\dagger, 1970-82$

\begin{tabular}{|c|c|c|c|c|c|c|c|c|c|c|c|c|c|c|c|c|}
\hline \multirow[b]{3}{*}{ Cancer site } & \multicolumn{8}{|c|}{ Blue collar } & \multicolumn{8}{|c|}{ White collar } \\
\hline & \multicolumn{2}{|c|}{ Total } & \multicolumn{2}{|c|}{ Smoker } & \multicolumn{2}{|c|}{ Non-smoker } & \multicolumn{2}{|c|}{ Unknown } & \multicolumn{2}{|c|}{ Total } & \multicolumn{2}{|c|}{ Smoker } & \multicolumn{2}{|c|}{ Non-smoker } & \multicolumn{2}{|c|}{ Unknown } \\
\hline & Obs & $S M R$ & Obs & $S M R$ & Obs & $S M R$ & Obs & $S M R$ & Obs & $S M R$ & Obs & $S M R$ & Obs & $S M R$ & Obs & $S M R$ \\
\hline $\begin{array}{l}\text { Kidney } \\
\text { Pancreas } \\
\text { All lymphatic and } \\
\text { haematopoietic }\end{array}$ & $\begin{array}{l}18 \\
32 \\
41\end{array}$ & $\begin{array}{l}246^{\star} \\
146 \\
130\end{array}$ & $\begin{array}{l}14 \\
22 \\
33\end{array}$ & $\begin{array}{l}257^{\star} \\
140 \\
149^{\star}\end{array}$ & $\begin{array}{l}2 \\
5 \\
3\end{array}$ & $\begin{array}{r}169 \\
144 \\
60\end{array}$ & $\begin{array}{l}2 \\
5 \\
5\end{array}$ & $\begin{array}{l}283 \\
185 \\
120\end{array}$ & $\begin{array}{l}0 \\
6 \\
7\end{array}$ & $\begin{array}{r}0 \\
113 \\
86\end{array}$ & $\begin{array}{l}0 \\
4 \\
5\end{array}$ & $\begin{array}{r}0 \\
116 \\
99\end{array}$ & $\begin{array}{l}0 \\
0 \\
1\end{array}$ & $\begin{array}{r}0 \\
0 \\
58\end{array}$ & $\begin{array}{l}0 \\
2 \\
1\end{array}$ & $\begin{array}{r}0 \\
277 \\
75\end{array}$ \\
\hline $\begin{array}{l}\text { Leukaemia } \\
\text { Lympho/reticulosarcoma } \\
\text { Other lymph }\end{array}$ & $\begin{array}{r}18 \\
7 \\
12\end{array}$ & $\begin{array}{l}128 \\
157 \\
116\end{array}$ & $\begin{array}{r}15 \\
6 \\
10\end{array}$ & $\begin{array}{l}154 \\
188 \\
132\end{array}$ & $\begin{array}{l}2 \\
0 \\
1\end{array}$ & $\begin{array}{r}89 \\
0 \\
60\end{array}$ & $\begin{array}{l}1 \\
1 \\
1\end{array}$ & $\begin{array}{r}47 \\
183 \\
88\end{array}$ & $\begin{array}{l}3 \\
2 \\
0\end{array}$ & $\begin{array}{r}84 \\
158 \\
0\end{array}$ & $\begin{array}{l}1 \\
2 \\
0\end{array}$ & $\begin{array}{r}46 \\
249 \\
0\end{array}$ & $\begin{array}{l}1 \\
0 \\
0\end{array}$ & $\begin{array}{r}136 \\
0 \\
0\end{array}$ & $\begin{array}{l}1 \\
0 \\
0\end{array}$ & $\begin{array}{r}155 \\
0 \\
0\end{array}$ \\
\hline
\end{tabular}

$\star$ Statistically significant based on $95 \%$ CIs.

†Not collected for 1978-82 new employees.

ers had a significantly raised SMR for kidney cancer $(S M R=193,95 \%$ CI 119-295), due in large part to findings from the Baton Rouge plant.

PLANT-SPECIFIC MORTALITY ANALYSES

Baton Rouge Table 5 shows selected SMRs for men at the Baton Rouge refinery and chemical plant stratified by potential exposure group and smoking. All the deaths from kidney cancer were in blue collar workers, resulting in significantly increased SMRs for all blue collar workers and for known smokers. The SMRs for non-smokers and those with un- 
Table 6 SMRs for kidney cancer, pancreatic cancer, and leukaemia deaths in Baton Rouge blue collar men, $1970-82$ cohort

\begin{tabular}{|c|c|c|c|c|c|c|c|c|c|c|c|c|c|}
\hline & & \multicolumn{3}{|c|}{ By year employed } & \multicolumn{3}{|c|}{ By age first employed } & \multicolumn{3}{|c|}{ By latency } & \multicolumn{3}{|c|}{ By duration employed } \\
\hline & & $\begin{array}{l}\text { Before } \\
1940\end{array}$ & $\begin{array}{l}1940 \text { to } \\
1949\end{array}$ & $\begin{array}{l}1950 \text { or } \\
\text { later }\end{array}$ & $\begin{array}{c}<20 \\
\text { years }\end{array}$ & $\begin{array}{l}20 \text { to } 29 \\
\text { years }\end{array}$ & $\begin{array}{l}\geqslant 30 \\
\text { years }\end{array}$ & $\begin{array}{l}<20 \\
\text { years }\end{array}$ & $\begin{array}{l}20 \text { to } 29 \\
\text { years }\end{array}$ & $\begin{array}{l}\geqslant 30 \\
\text { years }\end{array}$ & $\begin{array}{c}<20 \\
\text { years }\end{array}$ & $\begin{array}{l}20 \text { to } \\
\text { years }\end{array}$ & $\begin{array}{l}\geqslant 30 \\
\text { years }\end{array}$ \\
\hline $\begin{array}{l}\text { Kidney } \\
\text { cancer } \\
\text { Pancreatic } \\
\text { cancer } \\
\text { Leukaemia }\end{array}$ & $\begin{array}{l}\text { Obs } \\
\text { SMR } \\
\text { Obs } \\
\text { SMR } \\
\text { Obs } \\
\text { SMR }\end{array}$ & $\begin{array}{c}6 \\
180 \\
20 \\
180^{\star} \\
4 \\
50\end{array}$ & $\begin{array}{c}10 \\
260^{\star} \\
12 \\
120 \\
13 \\
210^{\star}\end{array}$ & $\begin{array}{c}2 \\
1000^{\star} \\
0 \\
0 \\
1 \\
130\end{array}$ & $\begin{array}{r}1 \\
200 \\
1 \\
80 \\
1 \\
140\end{array}$ & $\begin{array}{r}6 \\
150 \\
14 \\
130 \\
10 \\
140\end{array}$ & $\begin{array}{c}11 \\
380^{\star} \\
17 \\
180 \\
7 \\
110\end{array}$ & $\begin{array}{r}0 \\
0 \\
0 \\
0 \\
1 \\
170\end{array}$ & $\begin{array}{c}5 \\
420^{\star} \\
0 \\
0 \\
0 \\
0\end{array}$ & $\begin{array}{c}13 \\
220^{\star} \\
21 \\
170^{\star} \\
17 \\
140\end{array}$ & $\begin{array}{r}2 \\
250 \\
2 \\
80 \\
2 \\
100\end{array}$ & $\begin{array}{c}8 \\
330^{\star} \\
7 \\
100 \\
8 \\
180\end{array}$ & $\begin{array}{c}8 \\
200 \\
23 \\
190^{\star} \\
8 \\
90\end{array}$ \\
\hline
\end{tabular}

known smoking histories were also raised based on two observed deaths in each subgroup. The SMRs for pancreatic cancer were raised for all blue collar subgroups and for white collar smokers and unknowns. The SMR for all haematopoietic and lymphatic cancers was significantly raised for blue collar smokers, and not raised in any of the white collar subgroups. Likewise, there were more deaths from leukaemia and lymphoma than expected in blue collar smokers.

Table 6 further evaluates the kidney and pancreatic cancer and leukaemia SMRs in the Baton Rouge blue collar men. The SMRs for kidney cancer were increased for all employment periods and significantly increased for those hired during or after 1940. Similarly, all age at hire groupings had raised SMRs with a significant increase for those hired at 30 or more years of age. Grouping the subjects by latency showed SMRs that were significantly increased after 20 years from initial employment. Analyses by duration of employment showed increased mortality for all durations, with a significant increase for those employed for 20 to 29 years.

For pancreatic cancers, the SMR was significantly increased in men who were hired before 1940 $(S M R=180,95 \%$ CI 110-278), and slightly increased for those hired in the 1940s (SMR $=120$, 95\% CI 62-210). There were more deaths than expected for those hired at age 20 or more, particularly among those more than 30 years old at hire

Table 7 Frequency of leukaemia cell types by job category for Baton Rouge male employees 1970-82

\begin{tabular}{|c|c|c|c|c|}
\hline \multirow[b]{2}{*}{$\begin{array}{l}\text { Type of } \\
\text { leukaemia (ICD-8) }\end{array}$} & \multicolumn{3}{|c|}{ Baton Rouge } & \multirow[b]{2}{*}{ Totals } \\
\hline & $\begin{array}{l}\text { Blue } \\
\text { collar }\end{array}$ & $\begin{array}{l}\text { White } \\
\text { collar }\end{array}$ & Unknown & \\
\hline $\begin{array}{l}\text { Lymphatic } \\
\quad(204 \cdot 0,204 \cdot 1,204 \cdot 9) \\
\text { Acute myeloid }(205 \cdot 0) \\
\text { Chronic myeloid }(205 \cdot 1) \\
\text { Myeloid unspecified }(205 \cdot 9) \\
\text { Acute monocytic }(206 \cdot 0) \\
\text { Other and unspecified } \\
(207 \cdot 0,207 \cdot 1,207 \cdot 9)\end{array}$ & $\begin{array}{r}8 \\
4 \\
2 \\
- \\
- \\
4\end{array}$ & $\begin{array}{l}1 \\
1 \\
1 \\
- \\
-\end{array}$ & $\begin{array}{l}1 \\
- \\
- \\
-\end{array}$ & $\begin{array}{r}10 \\
6 \\
3 \\
- \\
- \\
4\end{array}$ \\
\hline Totals & 18 & 3 & 2 & 23 \\
\hline
\end{tabular}

$(S M R=180,95 \%$ CI 105-288). All of the deaths for blue collar workers were in subjects with at least 30 years latency. Most of the pancreatic deaths also occurred in workers with at least 30 years of employment, which resulted in a significantly increased SMR (SMR = 190, 95\% CI 120-285).

For the deaths from leukaemia, there was a significant increase only in men hired during the 1940 s (SMR $=210,95 \%$ CI 112-359). There was no trend by age at hire. Most of the deaths from leukaemia occurred in men with at least 30 years latency $(n=17)$ and 20 or more years duration of employment $(n=16)$, but the corresponding SMRs were not significant.

Table 7 lists the ICD-8 classification for the 23 leukaemia deaths in Baton Rouge. Six of the 23 leukaemia deaths were classified as acute myelogenous leukaemia (AML). Focusing on the subgroup of blue collar workers who were hired in the 1940s, two of the 13 leukaemia deaths were AMLs.

Baytown Attention at the Baytown refinery and chemical plant focused on the one cancer found to be somewhat increased for the total plant populationnamely, brain/CNS cancer. Also, the category of benign neoplasms was reviewed as many of these tumours involved the CNS. For Baytown men nonsignificant increases in brain/CNS cancer and benign neoplasm SMRs occurred in blue and white collar smokers and non-smokers, but these were based on small numbers. Mortality from benign neoplasms was increased in white collar more than in blue collar workers.

Due to the small number of brain cancers in Baytown blue collar men $(n=10)$, the SMRs by latency and duration are somewhat unstable. The SMRs were raised for all three employment year groups, but somewhat more so for those employed during 1940-9 (SMR $=210,95 \%$ CI 77-457). Seven of the 10 cases were 20-29 years old when hired and three were 30 or more years old. All the latency groups had increased SMRs, but most of the cases had 30 or more years of latency $(n=6)$. Five cases worked for 20-29 years, and four had a duration of 30 or more years.

Bayway/Bayonne The SMR for ischaemic heart 
disease was significantly high in Bayway/Bayonne blue collar workers reflecting a 9\% (95\% CI 107-117) increase over state rates, and was significantly low in white collar workers. SMRs were not significantly increased for any of the smoking subgroups, but more than half of the deaths had an unknown smoking history. Further examination of SMRs for blue collar workers showed that most of the deaths were in men who were hired before 1940 and that the SMR was significantly increased for men who began employment at 30 or more years of age $(S M R=114$, $95 \%$ CI 104-125). An overwhelming majority had 30 or more years latency $(n=805)$, whereas those with 20-29 years latency had a significantly low SMR (SMR $=67,95 \%$ CI 44-97). The SMRs were slightly higher in those who had worked for less than 30 years.

Laboratory workers In one analysis, SMRs for laboratory workers were considered separately from white collar workers. There were very few deaths in this group $(n=49)$ and no significant mortality excesses.

\section{Discussion}

Evaluation of death rates for our study population showed these to be lower than expected based on state mortality for all causes of death, all cancers, and respiratory diseases. These results are consistent with findings from other historical cohort studies of refinery and petrochemical workers. ${ }^{1-8}$ The inclusion of a large group of retirees and older employees in this cohort differs somewhat from other petrochemical populations which have tended to include a high percentage of younger active and terminated workers. Accordingly, a strength of this study is that it allows for the detailed examination of mortality among long term workers with extremely long latency periods. One limitation is that data were not available for retired workers who died before 1 January 1970. Their inclusion may have contributed additional information, but we do not believe that the lack of this information compromises the validity of the data that were collected and analysed.

It is difficult to interpret differences in mortality among the three refinery petrochemical complexes based on what we know about the histories of the plants. The significant increase in kidney cancer in the Baton Rouge population is of interest. Concern about kidney cancer among refinery populations stemmed from the results of a toxicological study that exposed rats to wholly vapourised unleaded petroleum. The study found a dose related incidence of kidney tumours among male rats, but not among female rats. ${ }^{17}$ Epidemiological studies of kidney cancer among refinery workers have been largely negative. One exception was the Exxon 1970-7 cohort study of refinery and chemical plant workers. In this study, rates for kidney cancer were increased at each of the three plant locations. Eighteen of the 22 cases were in the subpopulation of operators, mechanics, and labourers, giving a directly adjusted mortality of 1.6 per 10000 person-years compared with the United States rate of $1 \cdot 1 .^{2}$ The increase was not statistically significant. With the additional five years of data, the excess appears to have become more prominent at Baton Rouge, exclusively among blue collar workers, and to have diminished at Bayway/ Bayonne and Baytown. The only other study with an excess of kidney cancer was a United Kingdom study of distribution workers, which showed a slight kidney cancer excess concentrated among lorry drivers. ${ }^{18}$

Mortality from kidney cancer by smoking state for blue collar workers showed increases in smokers, non-smokers, and those with unknown smoking histories, but was most pronounced among known smokers. Fourteen of the 18 deaths were known smokers and two had smoking unknown. As none of the deaths from kidney cancer were in the white collar workers, it was not possible to separate the effects of smoking from the effects of potential workplace exposure.

Because smoking is a risk factor for kidney cancer in the general population, proper control for smoking would involve calculating SMRs for Exxon smokers and non-smokers $v$ death rates from kidney cancer for the respective general population groups. As smoking specific rates are not available for the general population, however, comparisons with rates for the general population include a mixture of smokers and non-smokers in the comparison group. Therefore, SMRs for Exxon smokers are overestimated and SMRs for non-smokers are underestimated for any disease that is related to smoking. Even though the SMRs in blue collar non-smokers and unknown smokers are based on extremely small numbers, the fact that the SMRs are increased in all three subgroups argues against smoking as an explanation for the raised SMR for kidney cancer. The smoking analyses are further limited by the crudeness of the smoking data, specifically the lack of information regarding the amount smoked, the type of cigarettes, or changes in smoking habits over time.

The raised SMRs for kidney cancer in men hired during the 1940s and in men 30 or more years old at the time of hire, suggests that there could have been unique service or other occupational influences during the war years. We have no information to evaluate this further.

The detailed individual work histories for the Baton Rouge kidney cancer cases were reviewed by local refinery and chemical plant management. It was difficult to determine exact work locations for many of the cases, especially the mechanics who often worked in many areas of the plants. It was also impossible to determine what their specific occupational exposures 
may have been, preventing firm conclusions concerning occupational exposures and the kidney cancer findings. The American Petroleum Institute (API) recently completed a case-control study of kidney cancers in five major petroleum companies and included many of Exxon's cases. An exposure matrix was utilised to evaluate the individual work histories and exposures. The results of this multicompany study indicate that all the comparisons between kidney cancer and refinery exposures showed either no association or weak, non-significant associations (Poole C, Satterfield MH, Levin L, Rothman KJ, Dreyer NA, personal communication).

It can be seen in tables 3 and 4 that the SMR for leukaemia is raised for all white collar workers and less than expected for blue collar workers. The nonsignificant excess of leukaemia (23 observed, 18 expected) in Baton Rouge, with most of the deaths in the blue collar/smoker subgroup, is the reverse situation and suggests that a different set of circumstances may have been present in the Baton Rouge population. Of the 23 total leukaemia deaths, $26 \%$ $(n=6)$ were classified as AMLs. In the Surveillance Epidemiology End Results (SEER) data for all age groups for the period $1973-7,,^{19} 31 \%$ of 2077 deaths from leukaemia were due to AMLs. Applying that proportion to the expected number of deaths from leukaemia gave 5.6 AMLs expected $v$ six observed, and provides no indication of an AML excess in this population. This indirect method for estimating the expected number of AMLs was used because state death rates for AMLs were included with other types of leukaemia. This method should somewhat underestimate the expected number of AMLs as SEER data included all ages and AMLs are more common in older age groups as in our study population.

Whereas it is clear that high level exposure to benzene contributes to a significant excess risk of leukaemia ${ }^{20}$ specifically AML, a relation has not been confirmed at the low benzene exposure typical of refinery environments. Most previous petrochemical studies did not find evidence of increased rates for these cancers. ${ }^{9}$ Excesses for leukaemia were reported in two studies on refinery workers ${ }^{91}$ (and Morgan RV and Wong $\mathrm{O}$, personal communication), but follow up analyses using available information on occupational exposure have been unable to identify specific causal agents. Further analyses of the leukaemia mortality by cell type in one of these studies showed an excess of lymphocytic leukaemia among deaths occurring before 1970 and an excess of AML in employees hired in 1940 or later and dying between 1970 and 1984 . It was suggested, but not confirmed, that this time restriction of the myelocytic leukaemia may have been related to increased use of benzene in the 1940s and later. Direct correlations with known exposures were not made. ${ }^{22}$
Pancreatic cancer was increased more so in blue collar workers in Baton Rouge than in white collar workers. Increases in pancreatic cancer have not been seen in other studies on petrochemical workers. ${ }^{18}$ This finding may reflect non-occupational risk factors. ${ }^{11}$

Cancers of the CNS/brain in Baytown occurred slightly more in blue collar workers than in white collar workers, but none of the SMRs were statistically significant. Some of the deaths classified as benign neoplasms based on nosological rules may have actually been due to malignant brain cancers; however, this would also be true for the deaths in the Texas general population used for comparison. Several studies of refinery and petrochemical workers, including the 1970-7 Exxon cohort study, have shown increased SMRs for cancer of the CNS/brain. Most of the differences in these studies were small and not statistically significant. ${ }^{19}$ In the original Exxon study, the overall SMR was 115; but in an internal comparison of potentially exposed (blue collar) with non-exposed (white collar) workers, the non-exposed CNS cancer mortality was higher. In one study of refinery workers, there was a $26 \%$ excess of CNS cancer but no consistent trend with duration of employment. ${ }^{5}$ In a study of Canadian refinery workers, the SMR was 390 and statistically significant, but it was based on only three cancer deaths. No common exposure could be identified. ${ }^{8}$ Delzell et al concluded that there is not sufficient evidence for an increased risk of CNS/brain cancer in refinery workers. ${ }^{9}$ Researchers at the University of Texas and Louisiana State University have been conducting a hospital based case-control study of brain/CNS cancers in the Gulf Coast area and Louisiana. Results from that study are expected in 1992.

The significantly increased SMR for ischaemic heart disease in blue collar workers in the New Jersey plants was examined further. Almost 400 of these deaths were in white men who had lived to the age of 85 or longer. The expected numbers of deaths for the age intervals $85-89,90-94$, and 95 or older may be underestimated as they are calculated using the death rates for those aged $\mathbf{8 5}$ or older, which is heavily weighted by the younger persons in that interval. Therefore, the increased SMR may be due, in part, to an underestimated expected number of deaths in the oldest age groups.

All the analyses based on main occupation omitted workers who had missing work histories. This included $1 \%$ of the Baton Rouge and Bayway/ Bayonne populations and $4 \%$ of the Baytown population. A further mortality analysis was performed for this small group. Most of the cause specific SMRs were increased, based on very small numbers. The two SMRs which were significantly high were for leukaemia in Baton Rouge, based on two deaths $(S M R=1333,95 \%$ CI 161-4816), and for all causes 
in Baytown, based on 88 deaths (SMR $=133,95 \%$ CI 106-163). We have no additional information to evaluate this group further.

\section{Conclusions}

Overall, the results of this study show lower than expected mortality for workers at all three plants and no indication of significant mortality excesses for specific causes of death across plants. The last findings contrast with the recent IARC review and are consistent with the previously referenced review of refinery worker studies. ${ }^{9}$ Among the cause specific mortality findings at individual plants, the excess of kidney cancer in blue collar workers at Baton Rouge would require a more detailed evaluation to assess more specifically the potential role of occupational exposures and smoking. A follow up case-control study of kidney cancer at Baton Rouge is planned. The study is expected to go beyond the API casecontrol analysis and will use additional sources for exposure assessment and a toxicology review to identify potential aetiological agents. The development of New Jersey state death rates for the groups aged 85 or older could be studied further, for comparison with the large group of very old retirees in the Bayway/Bayonne population.

We acknowledge the help of our many coworkers at Exxon Biomedical Sciences Inc and the Exxon Company, USA Headquarters Medical Staff. Eugene Sales helped us with vital status follow up and nosology, Gail Jorgensen provided database management and analytic support. Micki Vodarsik managed the data coding, data entry, and summarised the work histories. Jerry Lynch, CIH, and Bruce Simpson, $\mathrm{CIH}$, provided industrial hygiene support. We are grateful to Jeffrey Wacaser and Paul Theall for typing our many drafts.

1 Hanis NM, Shallenberger LG, Donaleski DL, Sales EA. A retrospective mortality study of workers in three major US refineries and chemical plants, part I: comparisons with US population, J Occup Med 1985;27:283-92.

2 Hanis NM, Shallenberger LG, Donaleski DL, Sales EA. A retrospective mortality study of workers in three major US refineries and chemical plants, part II: internal comparisons by geographic site, occupation, and smoking history, $J$ Occup Med 1985;27:361-9.

3 Wen CP, Tsai SP, McClellan WA, Gibson RL. Long-term mortality study of oil refinery workers, I. Mortality of hourly and salaried workers. Am J Epidemiol 1983;118:526-42.

4 Wen CP, Tsai SP, Gibson RL, McClellan WA. Long-term mortality study of oil refinery workers, II. Comparison of the experience of active, terminated, and retired workers. J Occup Med 1984;26:118-27.

5 Wong O, Morgan RW, Bailey W, et al. An epidemiologic study of petroleum refinery employees. Br J Ind Med 1986;43:6-17.

6 Divine BJ, Barron V. Texaco mortality study: II. Patterns of mortality among white males by specific job groups, $A m$ J Ind Med 1986;10:371-81.

7 Nelson NA, Van Peenen PFD, Blanchard AG. Mortality in a recent oil refinery cohort. J Occup Med 1987;29:610-7.

8 Theriault G, Provensher S. Mortality study of oil refinery workers: five year follow-up. J Occup Med 1987;29:357-61.

9 Delzell E, Austin H, Cole P. Epidemiologic studies of the petroleum industry. Occupational Medicine: State of the Art Reviews, 1988;3:455-74.

10 World Health Organisation, International Agency for Research on Cancer. Monographs on the evaluation of carcinogenic risks to humans: occupational exposures in petroleum refining; crude oil and major petroleum fuels. Lyon: WHO, IARC, 1989.

11 Falk RT, Pickle LW, Fontham ET, Correa P, Fraumeni JF. Life-style risk factors for pancreatic cancer in Louisiana: a case-control study. Am J Epidemiol 1988;128:324-6.

12 Acquavella JF, Donaleski D, Hanis NM. An analysis of mortality follow-up through the national death index for a cohort of refinery and petrochemical workers. Am J Ind Med 1986; 9:181-7.

13 Manual of the International Classification of Diseases, Injuries and Causes of Death, 8th ed. Geneva: World Health Organisation, 1967.

14 Marsh G. State mortality rates. University of Pittsburgh, Mortality and Population Data System. Pittsburgh: University of Pittsburgh (Sci) 1987.

15 Monson RR. Analysis of relative survival and proportional mortality. Comput Biomed Res 1974;7:325-32.

16 Rothman KJ, Boice JD. Epidemiologic analyses with a programmable calculator. Bethesda: National Institute of Health, 1979:(Publ No 79-1649).

17 MacFarland HN et al, eds. Chronic gasoline toxicology. Proceedings of the symposium. The toxicology of petroleum hydrocarbons. American Petroleum Institute 1982:78-86.

18 Wong O, Raabe GK. Critical review of cancer epidemiology in petroleum industry employees, with a quantitative metaanalysis by cancer site. Am J Ind Med 1989;15:283-310.

19 US Department of Health and Human Services, Surveillance, epidemiology, and end results: incidence and mortality data, 1973-77, National Cancer Institute Monograph 57, Bethesda: National Institute of Health, 1981:78-9.

20 Rinsky RA, Smith AB, Hornung R, et al. Benzene and leukemia: an epidemiologic risk assessment. $N$ Engl J Med 1987; 316:1044-50.

21 McCraw DS, Joyner RE, Cole P. Excess leukemia in a refinery population. J Occup Med 1985;27:220-2.

22 Wongsrichanalai C, Delzell E, Cole P. Mortality from leukemia and other diseases among workers at a petroleum refinery. $J$ Occup Med 1989;31:106-11.

Accepted 2 September 1991 